\title{
Evidence of growth-selective predation on larval Japanese anchovy Engraulis japonicus in Sagami Bay
}

\author{
Akinori Takasuka ${ }^{1, *}$, Ichiro Aoki $^{1}$, Isamu Mitani ${ }^{2}$ \\ ${ }^{1}$ Department of Aquatic Bioscience, Graduate School of Agricultural and Life Sciences, The University of Tokyo, 1-1-1 Yayoi, \\ Bunkyo, Tokyo 113-8657, Japan \\ ${ }^{2}$ Kanagawa Prefectural Fisheries Research Institute, Jyogashima, Misaki, Miura, Kanagawa 238-0237, Japan
}

\begin{abstract}
Growth-selective predation mortality was demonstrated for postlarval Japanese anchovy Engraulis japonicus in field research. The larval anchovy and their predatory fish were simultaneously captured by a trawl in Sagami Bay during October to November 2000. The growth rates analyzed by otolith microstructure were compared between the larvae from the stomach contents of the predators (prey larvae) and those from the population of origin (surviving larvae). The mean growth rates of the prey larvae collected on 28 October and 2 to 4 November (mean \pm SD: 0.57 $\left.\pm 0.07 \mathrm{~mm} \mathrm{~d}^{-1}\right)$ and on 23 November $\left(0.50 \pm 0.06 \mathrm{~mm} \mathrm{~d}^{-1}\right)$ were significantly lower than those of the corresponding surviving larvae $\left(0.63 \pm 0.07\right.$ and $0.54 \pm 0.06 \mathrm{~mm} \mathrm{~d}^{-1}$, respectively). Such significant differences were not explained by size-selective predation, but were due to variations in the mean growth rates at the same larval size (i.e. non-size-related). The mean growth rates of the prey larvae were different among predatory species (barracuda Sphyraena pinguis, Japanese sea bass Lateolabrax japonicus, white croaker Pennahia argentatus, Japanese jack mackerel Trachurus japonicus, Pacific round herring Etrumeus teres and juvenile anchovy). Comparisons of back-calculated daily growth rates showed that the decrease in growth rates of the prey larvae were consistent from directly after hatching up to predation. The larvae with lower growth rates were more vulnerable to predation, owing to the cumulative decline in growth rates from hatching to each encounter with predators, compared to the larvae with higher growth rates, even if they were the same size, at a given moment in the sea. Therefore, the level of growth rates itself had direct impact on vulnerability to predation for larval anchovy, independently of both size (size-selective mortality) and time (stage duration). In addition, such impacts could be predator specific. We propose the 'growth-selective predation' hypothesis (mechanism), which is theoretically independent of and synergistic with the existing hypotheses based on size and time under the general 'growth-mortality' concept for the survival process during the early life history of marine pelagic fish.
\end{abstract}

KEY WORDS: Growth rate - Vulnerability to predation · Otolith microstructure analysis · Larvae · Japanese anchovy $\cdot$ Sagami Bay $\cdot$ Growth-selective predation

Resale or republication not permitted without written consent of the publisher

\section{INTRODUCTION}

Pelagic fish have high mortality during early life history stages in general. This high mortality is attributed to predation, starvation, physical transport and sublethal factors, although the relative roles of these as determinants of recruitment remain unresolved (Anderson 1988, Bailey \& Houde 1989, Leggett \& DeBlois 1994). To better understand the mechanisms underlying the population fluctuations of pelagic fish, both biotic and abiotic factors have been examined and subsequently, a variety of hypotheses have been proposed. The relationship between growth rate and survival has been a focal point, as small variations in growth rates during early life history stages could lead to dramatic fluctuations in recruitment (Houde 1987, 1989). Consequently, many studies have suggested that lower growth rates during the larval and juvenile 
stages could result in higher mortality (Healey 1982, Post \& Prankevicius 1987, West \& Larkin 1987, Miller et al. 1988, Hovenkamp 1992, Rice et al. 1993, Campana 1996, Meekan \& Fortier 1996, Wilson \& Meekan 2002). A paradigm emerged that larger and/or faster growing individuals will survive better.

The 'growth-mortality' hypothesis (Anderson 1988) has been particularly used to explain recruitment dynamics. Hare \& Cowen (1997) grouped 3 functional mechanisms (hypotheses) - 'bigger is better', 'growth rate' and 'stage duration' - into this general concept. In the 'bigger is better' hypothesis, it was postulated that larger individuals are less vulnerable to mortality than smaller individuals and that at a given age will have a higher probability of survival (see Miller et al. 1988). Although there is evidence that larger individuals have experienced higher mortality (Fuiman 1989, Litvak \& Leggett 1992, Pepin et al. 1992, Leggett \& DeBlois 1994, Gleason \& Bengtson 1996a,b), the theory could be correct under certain conditions, such as strongly negative size selection by predators and the declining number of potential predators as prey size increases. Similarly, the 'growth rate' concept is also based on the assumption that mortality is negatively size dependent (Hare \& Cowen 1997). If so, faster growing larvae should experience shorter high mortality periods (Ware 1975, Shepherd \& Cushing 1980). The idea focusing on age at metamorphosis is the 'stage duration', in which faster growing larvae are considered to have a higher probability of survival by means of shortening the high mortality larval stage and developing into the juvenile stage faster (Chambers \& Leggett 1987, Houde 1987).

Within certain limitations, these hypotheses serve to explain the growth-survival relationship. However, they are based on 2 theories: size (negative size-dependent mortality) and time (stage duration). Size is an outcome of growth, and mortality due to protracted stage duration (time) is dependent on integrated cumulative probabilities of lethal events throughout high mortality stages. Therefore, the relationship between growth and survival remains indirect, at least from 2 viewpoints; firstly that the existence of non-size-related effects has rarely been considered, nor incorporated into the theoretical framework; secondly, that what is happening at a given moment in the sea is always speculative.

In the early studies, mortality due to starvation linked with food supply and feeding success was regarded as the determinant of recruitment success according to the 'critical period' (Hjort 1914), 'match-mismatch' (Cushing 1975, 1990) and 'ocean stability' (Lasker 1975, 1978) hypotheses. Recent studies, however, have not conclusively linked starvation with year-class strength (Anderson 1988, Leggett \& DeBlois 1994). Alternatively, predation pressure has been indicated as the primary and direct source of mortality for larval and juvenile stages (Bailey \& Houde 1989), although starvation and predation are not exclusive, rather interactive factors as many authors have noted (e.g. Cushing 1990, 1995, Leggett \& DeBlois 1994). In accordance with this, predation has also been regarded as the major cause of mortality in the 'growth-mortality' hypothesis, although this integrates the processes of food supply and predation in the theory (Anderson 1988). Nonetheless, no evidence has yet been obtained to support the predation part of the 'growth-mortality' hypothesis in field conditions. Is a slower growing individual actually removed by predation in the sea?

Most previous studies on vulnerability to predation were conducted under laboratory and enclosure conditions, partly because the direct study of predation at sea is difficult. For example, the rapid digestion of prey fish and the patchy distributions of various predators contribute to this difficulty (Anderson 1988). Moreover, prey-predator interactions in the limited space of tanks and enclosures are not always applicable to the natural population in field conditions (Heath 1992). Even in a mesocosm study, poor ecological realism was reported (Kraufvelin 1999). Thus, in situ demonstrations are desirable in the real field.

Sagami Bay, Japan, is one of the biggest fishing grounds for Japanese anchovy Engraulis japonicus postlarvae 'shirasu'. Anchovy females spawn throughout the year, the main spawning season being from March to October. The eggs are transported by the Kuroshio Countercurrent and then become concentrated at the front formed by river runoff (Lindsay et al. 1998). The larvae then enter the coastal fishing ground to be the target of 'shirasu' fisheries (Mitani 1988). Some potentially predatory species are incidentally caught by commercial 'shirasu' trawl, indicating that those species forage larval anchovy, which consequently would suffer predation mortality. This situation appeared to satisfy our requirements for a field study on predation mortality of larval anchovy in relation to growth rates.

In the present study, we directly examined the growth rates of the larval Japanese anchovy from the stomach contents of their predatory fish by otolith microstructure analysis, and compared their growth rates with those of larvae from the population of origin, simultaneously captured in Sagami Bay. The principal aim was to demonstrate the existence of growth-selective predation mortality for larval anchovy in field conditions. This included testing the hypothesis that slower growing larvae are more vulnerable to predation mortality at a given moment in the field, and comparing larvae of the same size to investigate the existence of non-size-related mortality, regardless of size selection by predators. In addition, daily growth rates were back-calculated and the period and stages responsible for the differences in growth rates examined. 


\section{MATERIALS AND METHODS}

Field sampling. Japanese anchovy postlarvae and their potentially predatory fish were simultaneously captured by the same tows of a commercial 'shirasu' trawl with a mesh size (cod end) of $2.3 \mathrm{~mm}$ in Sagami Bay during October and November 2000. The net was towed for 5 to $10 \mathrm{~min}$ several times in the first few hours after sunrise, at an approximate depth of $10 \mathrm{~m}$ maximum, targeting postlarvae foraging just above the seabed during the daytime (Mitani 1988). The larval anchovy, which were randomly selected from the daily catch, and all the potentially predatory fish were immediately frozen at $-20^{\circ} \mathrm{C}$.

Larvae from the stomach contents of their predatory fish. After the standard length (SL) or fork length (FL) of each predatory fish was measured to the nearest $0.1 \mathrm{~mm}$, the stomach was dissected and then weighted to the nearest $0.01 \mathrm{~g}$. The stomach contents were examined under a binocular microscope and sorted for larval anchovy, which were then weighted to the nearest $0.01 \mathrm{~g}$ in pool per stomach. The percent contribution of anchovy larvae to the whole stomach by wet weight (anchovy weight contribution, AWC) was calculated for each predatory fish.

Concurrently with dissection, the positions of the larvae in the stomachs were classified into front, middle and back parts of the stomach (F, M and B, respectively). The larvae were ranked, from A to F, according to the extent of digestion, as follows. A: considered to be in fresh condition; B: integument has been digested; C: a portion of muscular tissue has been digested; D: more than half of the muscular tissue has been digested; E: almost all of the muscular tissue has been digested; F: only a set of vertebrae or eyeballs remain. Then, SLs of the larvae were measured, where possible.

The larvae dissected from the stomach contents of their predators must be the larvae actually ingested by the predators (prey larvae). The larvae captured simultaneously with the predators were regarded as the temporarily surviving larvae from the population of origin (surviving larvae) for comparison.

Growth rates by otolith microstructure analysis. After SL measurements had been made to the nearest $0.1 \mathrm{~mm}$, sagittal otoliths were dissected from individual larvae under a binocular microscope. The otoliths were mounted on a slide glass with euparal for subsequent growth analysis. Either the left or right otolith was used for analysis assuming they were symmetrical (Wang \& Tzeng 1999). For a series of otolith measurements, the otolith measurement system (Ratoc System Engineering) was used, which was composed of a transmitted light microscope and video camera connected to a monitor and computer. Along a measurement transect set from the nucleus to the outermost margin, maximum otolith radius (OR) and each daily growth increment width were measured to the nearest $0.1 \mu \mathrm{m}$. Tsuji \& Aoyama (1984) reported that Japanese anchovy completed yolk absorption at 2 to $3 \mathrm{~d}$ after hatching, and that the first daily growth increment was deposited at the start of external feeding ( 3 to $4 \mathrm{~d}$ ) at a temperature of $20^{\circ} \mathrm{C}$. Therefore, daily ages were determined as the number of daily growth increments plus 3. Hatching dates were calculated from the daily ages and dates of capture. SLs of $2.9 \mathrm{~mm}$ at hatching (Fukuhara \& Takao 1988) and $5.6 \mathrm{~mm}$ at completion of yolk absorption (Fukuhara 1983) were adopted. Then, individual mean growth rates from hatching to capture or predation were calculated by dividing SL minus 2.9 by the daily ages (Aoki \& Miyashita 2000). SL and daily growth rate at each daily age were back-calculated for individual larvae by the biological intercept method (Campana 1990, Campana \& Jones 1992, Watanabe \& Kuroki 1997) with SL at the first ring deposition fixed at $5.6 \mathrm{~mm}$, after determining an allometric relationship between OR and SL for each larva (see 'Results'). Otolith preparation, measurements and growth analyses were conducted in the same way for the prey larvae and surviving larvae.

SL restoration for prey larvae. SL measurement of the semi-digested larvae in the stomachs was often impossible to carry out, or unreliable. In such cases, SLs were restored from measured OR data by using the OR-SL relationship of the larvae from the population of origin. The SL restoration could, however, lead to bias due to its monistic restoration process, if somatic growth rates affected the OR-SL relationship (see 'Discussion'). To examine the effects of growth rates on the OR-SL relationship, the surviving larvae were classified into 3 groups according to the level of mean growth rates (Group $\mathrm{H}$ : high-order one-third; Group M: middle-order one-third; Group L: low-order one-third). Then, an analysis of covariance (ANCOVA) was applied to test the effects of groups on ln-transformed SL with ln-transformed OR as a covariate. For additional validation, SL restoration was also applied to the prey larvae with measured SLs available and then restored estimates were compared with actual measurements by a Student's t-test.

Comparative analysis. The mean growth rates from hatching to capture or predation, the $5 \mathrm{~d}$ mean growth rates (mean growth rates every $5 \mathrm{~d}$ ), and the recent mean growth rates from 3, 7 and $14 \mathrm{~d}$ before capture or predation were compared between the prey larvae and surviving larvae by means of a Student's $t$-test. SLs were also compared between them with a Student's $t$-test, and size selectivity of the predators was described to examine whether the differences in growth rates were due to size-selective predation or not. To examine the differences in the mean growth rates among positions and digestion ranks of the larvae in the stom- 
achs and among predatory species, a 1-way analysis of variance (ANOVA) was used. An ANCOVA was applied for ln SLs using ln OR as a covariate, in order to find out the differences in OR-SL relationships. Comparisons of the mean growth rates at the same size between the prey larvae and surviving larvae were also conducted by ANCOVA, with SL as a covariate.

\section{RESULTS}

\section{Predatory fish and prey larvae}

In total, the stomach contents of 8 potentially predatory species and 65 fish were examined (Table 1). A total of 337 larvae were dissected from 7 species and 35 individuals (Table 2). Although the number of larvae and the value of AWC (\%) varied to some extent, larval anchovy were the predominant component of the stomach contents of these predatory fish and were considered to constitute a major energy source for them. Sagittal otoliths were obtained from 155 larvae in total. SLs of 72 larvae were measured for growth analysis; SLs of the remaining 83 larvae were restored from measured OR data prior to growth analysis.

\section{Hatching date distribution}

According to dates of capture and hatching date distributions, the prey larvae and surviving larvae were divided into 3 and 2 groups $\left(\mathrm{P}_{0}, \mathrm{P}_{1}, \mathrm{P}_{2}\right.$ and $\mathrm{S}_{1}, \mathrm{~S}_{2}$, respectively) (Fig. 1). The prey larvae collected on 4 and 5 October were pooled into $\mathrm{P}_{0} . \mathrm{P}_{1}$ was the prey larvae on 28 October and 2 to 4 November. The surviving larvae captured on 28 October and 3 November were pooled into $\mathrm{S}_{1}$, which corresponded to $\mathrm{P}_{1}$. The prey larvae $\mathrm{P}_{2}$ and its corresponding surviving larvae $\mathrm{S}_{2}$ were collected on the same day, 23 November. The peak of $S_{1}$ hatching dates was early in October, while that of $\mathrm{S}_{2}$ was after the middle of October. The bulk of the $\mathrm{P}_{0}$ hatching dates were not included in the range of $S_{1}$, and the mean hatching date of $\mathrm{P}_{0}$ was ca. 1 mo before that of $\mathrm{S}_{1}$.

\section{Positions and digestion ranks in the stomachs}

The number of larvae was not highly partial both among the positions (Table 3) and digestion ranks except for the relative rarity of digestion rank $\mathrm{A}$ (Table 4). There were no significant differences in the mean growth rates of the prey larvae among the positions in the stomachs (ANOVA, $\mathrm{p}>0.05)$. Comparisons among the digestion ranks $(\mathrm{A}-\mathrm{B}, \mathrm{C}-\mathrm{D}$ and $\mathrm{E}-\mathrm{F})$ also showed no significant differences (ANOVA, $p>0.05$ ) except slightly lower growth rates of A-B larvae for $P_{0}$ $(0.01<\mathrm{p}<0.05)$.

\section{SL restoration for prey larvae}

An allometric formula was well fitted for the relationship between OR and SL of the surviving larvae. Since the slopes of $\ln$ SL against ln OR were different between $S_{1}$ and $S_{2}(p<0.001)$, the OR-SL relationship of the corresponding surviving larvae was used separately for restoration of SL of the prey larvae (Fig. 2). The formula obtained from $S_{1}$ was also used for SL restoration for $\mathrm{P}_{0}$, which had no corresponding surviving larvae, as a matter of convenience.

Application of ANCOVAs showed significant differences in ln SL among the 3 groups ( $\mathrm{H}, \mathrm{M}$ and $\mathrm{L}$ )

Table 1. Samples and date of capture of larvae and their potentially predatory species collected in Sagami Bay during October to November 2000

\begin{tabular}{|c|c|c|c|c|c|c|c|c|c|}
\hline \multirow{2}{*}{ Fish species } & \multicolumn{9}{|c|}{ Date of capture (2000) } \\
\hline & 4 Oct & 5 Oct & 28 Oct & $2 \mathrm{Nov}$ & $3 \mathrm{Nov}$ & $4 \mathrm{Nov}$ & $9 \mathrm{Nov}$ & $23 \mathrm{Nov}$ & Total \\
\hline \multicolumn{10}{|l|}{ Larvae } \\
\hline Engraulis japonicus ${ }^{\mathrm{a}}$ & & & 60 & & 60 & & & 120 & 240 \\
\hline \multicolumn{10}{|l|}{ Predator } \\
\hline Sphyraena pinguis & 5 & 2 & 1 & 1 & 2 & & & 3 & 14 \\
\hline Lateolabrax japonicus & 1 & & & & & 2 & & & 3 \\
\hline Pennahia argentatus & 4 & & & & & 2 & & & 6 \\
\hline Trachurus japonicus & 17 & 2 & & 7 & 4 & 1 & & & 31 \\
\hline Etrumeus teres & & & 3 & & & & & 3 & 6 \\
\hline Sillago japonica & & 1 & & & & & & & 1 \\
\hline Chelidonichthys spinosus & & & & & 1 & & 1 & & 2 \\
\hline Engraulis japonicus ${ }^{\mathrm{b}}$ & & & 2 & & & & & & 2 \\
\hline Total for predator & 27 & 5 & 6 & 8 & 7 & 5 & 1 & 6 & 65 \\
\hline
\end{tabular}


Table 2. Stomach content analysis of the different predatory species. n: number of predators examined; n': number of predators preying on larvae; length: fork length for Trachurus japonicus and standard length for the other species; AWC: anchovy weight contribution to the whole stomach of predator. Range and mean data calculated for all individuals examined (n); AWC and number in the stomachs also included data for juveniles as stage distinction for the prey individuals proved difficult

\begin{tabular}{|c|c|c|c|c|c|c|c|c|c|c|}
\hline \multirow[t]{3}{*}{ Predatory fish species } & \multirow[t]{3}{*}{$\mathrm{n}$} & \multirow[t]{3}{*}{$\mathrm{n}^{\prime}$} & \multicolumn{2}{|c|}{ Length (mm) } & \multicolumn{2}{|c|}{ AWC (\%) } & \multirow{2}{*}{\multicolumn{3}{|c|}{$\begin{array}{c}\text { Number of larvae } \\
\text { in the stomachs }\end{array}$}} & \multirow{3}{*}{$\begin{array}{l}\text { Otolith } \\
\text { analyzed }\end{array}$} \\
\hline & & & \multirow[t]{2}{*}{ Range } & \multirow[t]{2}{*}{ Mean } & \multirow[t]{2}{*}{ Range } & \multirow[t]{2}{*}{ Mean } & & & & \\
\hline & & & & & & & Range & Mean & Total & \\
\hline Sphyraena pinguis & 14 & 9 & $155.1-255.5$ & 202.2 & $0-94.5$ & 29.8 & $0-28$ & 5.7 & 80 & 17 \\
\hline Lateolabrax japonicus & 3 & 3 & $179.7-209.7$ & 197.1 & $5.8-52.5$ & 24.8 & $3-43$ & 18.3 & 55 & 27 \\
\hline Pennahia argentatus & 6 & 4 & $115.1-128.2$ & 120.7 & $0-50.0$ & 24.2 & $0-12$ & 3.3 & 20 & 18 \\
\hline Trachurus japonicus & 31 & 13 & 89.7-137.6 & 113.8 & $0-72.7$ & 17.6 & $0-27$ & 3.1 & 96 & 44 \\
\hline Etrumeus teres & 6 & 3 & $119.3-147.5$ & 134.1 & $0-31.7$ & 12.5 & $0-30$ & 10.0 & 60 & 40 \\
\hline Sillago japonica & 1 & 1 & - & 158.0 & - & 30.5 & - & 2.0 & 2 & 0 \\
\hline Chelidonichthys spinosus & 2 & 0 & $199.7-203.4$ & 201.6 & - & 0.0 & - & 0.0 & 0 & 0 \\
\hline Engraulis japonicus ${ }^{\mathrm{a}}$ & 2 & 2 & $67.4-69.5$ & 68.5 & - & 45.5 & $11-13$ & 12.0 & 24 & 9 \\
\hline Total & 65 & 35 & & & & & & & 337 & 155 \\
\hline
\end{tabular}

divided by the level of mean growth rates, with ln OR as a covariate (Fig. 3). The lowest growth group had larger otoliths than the other 2 groups for $\mathrm{S}_{1}$ ( $p<0.01$ ), and the highest growth group had smaller otoliths than the others for $\mathrm{S}_{2}(\mathrm{p}<0.05)$. Comparison between estimates and measurements revealed that SLs restored from OR data were not significantly different from measured SLs for the prey larvae with actual measurements available (Student's $t$-test, $\mathrm{p}>$ $0.05 ; \mathrm{n}=72$ ).

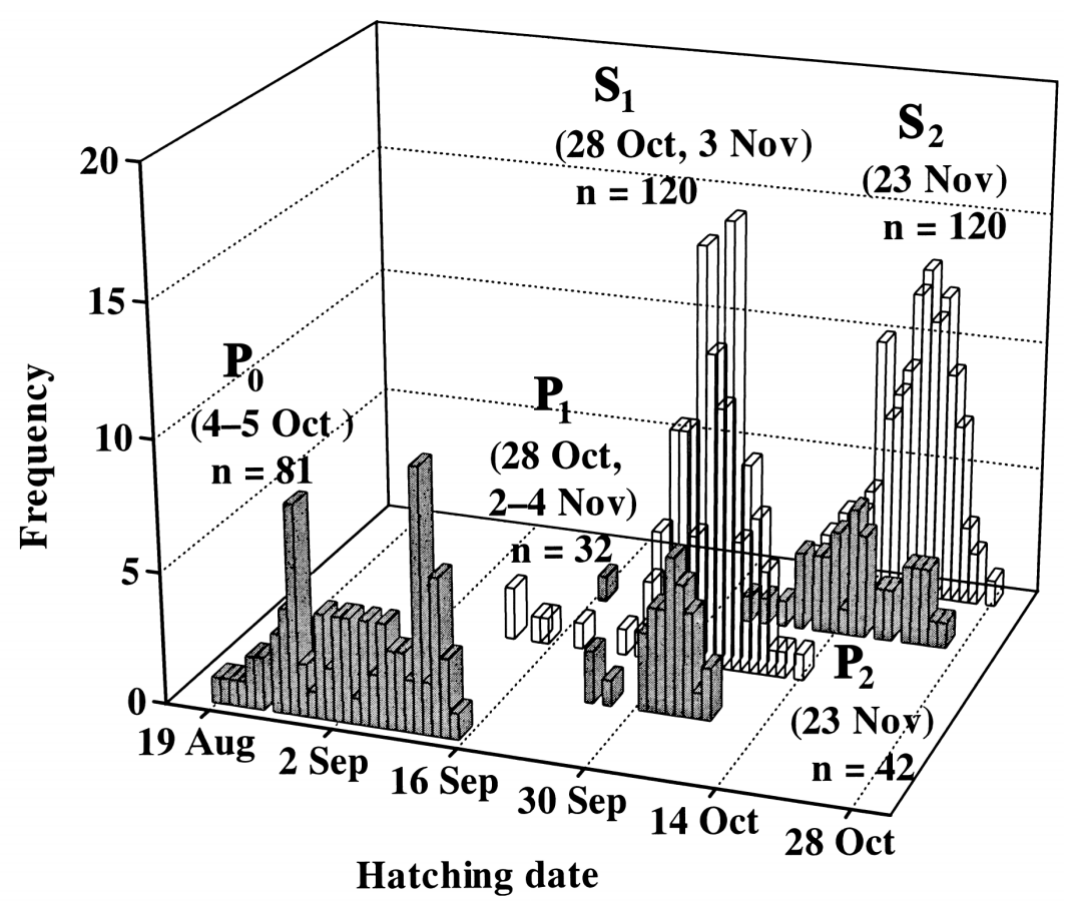

Fig. 1. Hatching date distributions of the prey larvae (solid: $\mathrm{P}_{0}, \mathrm{P}_{1}$ and $\mathrm{P}_{2}$ ) and surviving larvae (open: $S_{1}$ and $S_{2}$ ). Dates of capture indicated in parentheses

\section{Comparison of growth rates and SLs between prey larvae and surviving larvae}

Frequency distributions of the mean growth rates of the prey larvae $\left(\mathrm{P}_{0}, \mathrm{P}_{1}\right.$ and $\left.\mathrm{P}_{2}\right)$ and surviving larvae $\left(\mathrm{S}_{1}\right.$ and $\mathrm{S}_{2}$ ) are shown in Fig. 4 . The mean growth rates were $0.57 \pm 0.07$ (mean $\pm \mathrm{SD}$ ) $\mathrm{mm} \mathrm{d}^{-1}$ for $\mathrm{P}_{1}$ and $0.50 \pm$ $0.06 \mathrm{~mm} \mathrm{~d}^{-1}$ for $\mathrm{P}_{2}$, which were significantly lower than $0.63 \pm 0.07 \mathrm{~mm} \mathrm{~d}^{-1}$ for $\mathrm{S}_{1}$ and $0.54 \pm 0.06 \mathrm{~mm} \mathrm{~d}^{-1}$ for $\mathrm{S}_{2}$, respectively (Student's $t$-test, $\mathrm{p}<0.001$ ), although there were no significant differences between $\mathrm{P}_{0}\left(0.64 \pm 0.08 \mathrm{~mm} \mathrm{~d}^{-1}\right)$ and $\mathrm{S}_{1}$ $(\mathrm{p}>0.05)$. As was the case in OR-SL relationships (Fig. 2), there were significant differences in the mean growth rates between the 2 surviving samples ( $\mathrm{p}<0.001) ; \mathrm{S}_{2}$ had considerably lower growth rates.

On the other hand, no significant differences in the larval SLs were found between $\mathrm{P}_{1}$ and $\mathrm{S}_{1}(19.6 \pm 3.3$ and $20.3 \pm$ $3.3 \mathrm{~mm}$, respectively; Student's $t$-test, $\mathrm{p}>0.05)$, or between $\mathrm{P}_{2}$ and $\mathrm{S}_{2}(21.9 \pm 2.6$ and $21.7 \pm 1.9 \mathrm{~mm}$, respectively; p > 0.05) as shown in Fig. 5 (prey juvenile anchovy $>40 \mathrm{~mm}$ SL were excluded from comparisons). However, the sizes of the prey larvae differed slightly among predatory species. Although most of the prey larvae were in the size range of the surviving larvae (14 to $30 \mathrm{~mm}$ SL), barracuda Sphyraena pinguis and Japanese sea bass Lateolabrax japonicus tended to prey on larvae across a wider range of SL, and are capable of capturing larger larvae than the other species. The bar- 


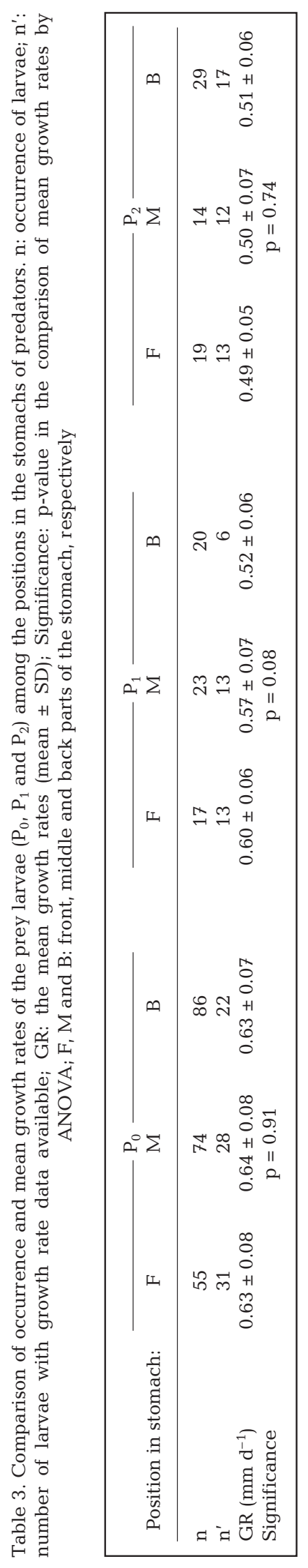

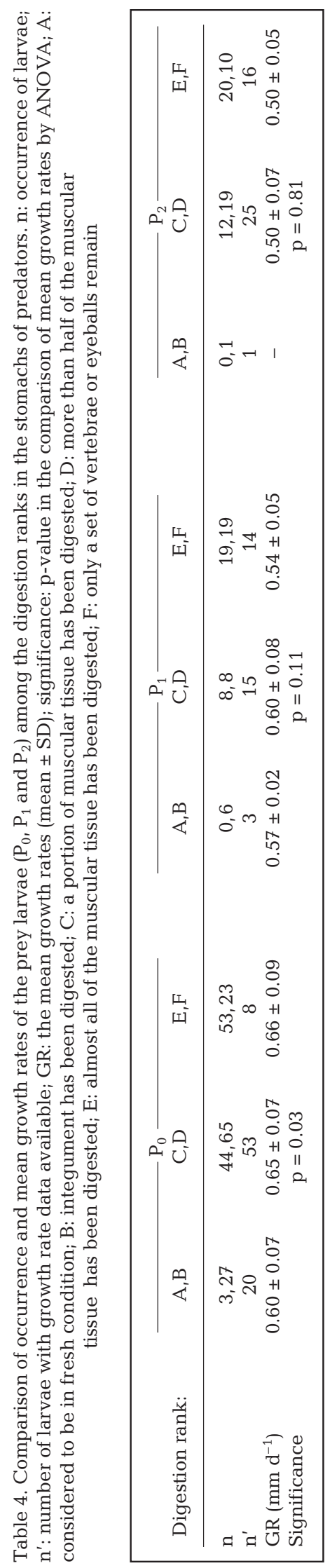

racuda stomachs also contained 3 juvenile anchovy (40 to $70 \mathrm{~mm}$ ). Juvenile anchovy were excluded from otolith examination and 2 of them were analyzed as a predatory species because of their cannibalism. In contrast to barracuda and Japanese sea bass, these juvenile anchovy indicated size-selective predation on smaller larvae.

Comparisons of the mean growth rates by ANCOVAs with SL as a covariate still showed that the growth rates of the prey larvae were clearly lower than those of the corresponding surviving larvae even if compared at the same size (Fig. 6). The mean growth rates were positively correlated with larval SLs for both $\mathrm{P}_{1}$ and $\mathrm{S}_{1}$, and the intercepts in the linear relationships differed significantly $(\mathrm{p}<0.001)$. Between $\mathrm{P}_{2}$ and $\mathrm{S}_{2}$, there were significant differences in the regression slopes of growth rates on SLs $(p<$ 0.001), showing that the prey larvae had lower growth rates within the range of SLs analyzed.

\section{Comparison of growth rates of prey larvae among predatory species}

Differences in the mean growth rates of the prey larvae were found among predatory species in 3 samples $\left(P_{0}, P_{1}\right.$ and $\left.P_{2}\right)$ (ANOVA, $\mathrm{p}<$ 0.01). Although the relative levels of mean growth rates of the prey larvae among predatory species fluctuated among samples, barracuda generally preyed on the larvae with higher growth rates (Fig. 7). On the other hand, lower growth rates were characteristic of the larvae from white croaker Argyrosomus argentatus, Pacific round herring Etrumeus teres and juvenile anchovy, which were the predators smaller than barracuda (Table 1).

\section{Back-calculated daily growth rates}

Overall, daily growth rates of the prey larvae pooled by daily age were consistently slightly lower than those of the surviving larvae from 5 $\mathrm{d}$ after hatching (Fig. 8a). In comparisons of $5 \mathrm{~d}$ mean growth rates, statistically significant differences from the surviving larvae were found at 5 to 10 and 21 to 25 daily ages for $P_{1}$ and 5 to 15 for $\mathrm{P}_{2}$ (Student's $t$-test, $\mathrm{p}<0.01$ ). Moreover, in data pooled by the days before capture or predation, consistent lower growth rates of the prey larvae were more distinct (Fig. 8b), and significant differences were found from at least 2 wk before predation $(\mathrm{p}<0.01)$. 


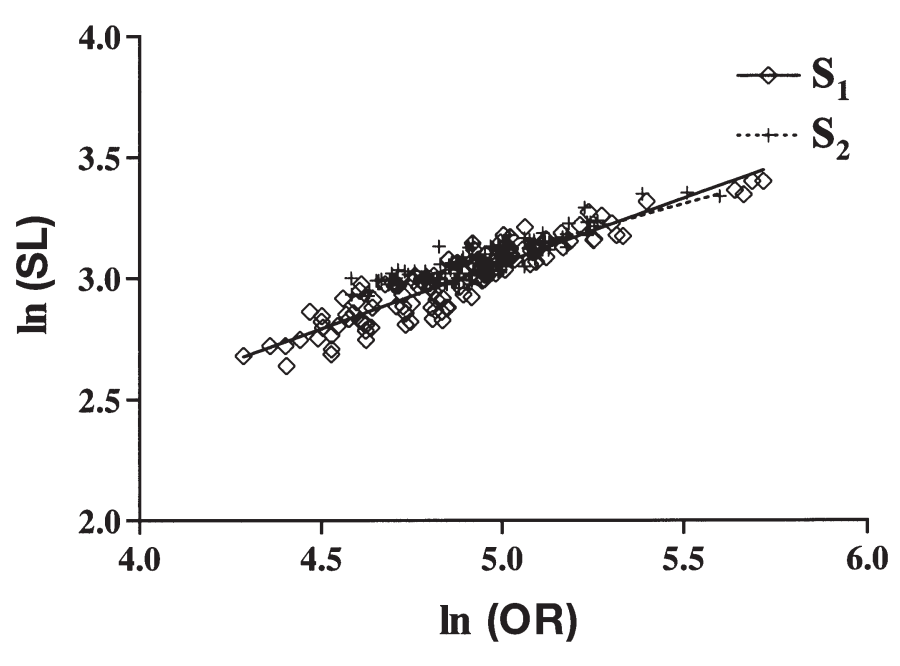

Fig. 2. Relationships between maximum otolith radius (OR) and standard length (SL) of the surviving larvae $\left(\mathrm{S}_{1}\right.$ and $\left.\mathrm{S}_{2}\right)$. $\mathrm{S}_{1}$ : $\ln \mathrm{SL}$ $=0.539 \ln \mathrm{OR}+0.367\left(\mathrm{r}^{2}=0.854, \mathrm{n}=120\right) ; \mathrm{S}_{2}: \ln \mathrm{SL}=0.418 \ln \mathrm{OR}$ $+1.009\left(r^{2}=0.786, n=120\right)$. Regressions of $\ln \mathrm{SL}$ on $\ln$ OR were compared between $\mathrm{S}_{1}$ and $\mathrm{S}_{2}$. The relationships for $\mathrm{S}_{1}$ and $\mathrm{S}_{2}$ were used for restoration of SL from measured OR data for the prey larvae, $\mathrm{P}_{1}\left(\right.$ also $\mathrm{P}_{0}$ ) and $\mathrm{P}_{2}$, respectively

\section{DISCUSSION}

\section{Sampling method and predation in the net}

An essential assumption in comparative studies between survivors and survivors plus non-survivors (non-survivors and temporary survivors in the present study) in the sea is that they originated from the same population or cohort (Meekan \& Fortier 1996), usually not easily proved (but see Tsukamoto et al. 1989, Yamashita et al. 1994). We satisfied this assumption by simultaneously capturing both larvae and the predators foraging them; however, in doing so, we may have generated another problem to be solved. Predation in the net, if indeed it happened, could lead to bias in field studies on the feeding ecology of fish (Purcell 1985, Bailey et al. 1993). Apart from the uniformity in the numbers of larvae among the positions in the stomachs and the wide range of digestion extent with larvae in fresh condition occurring only rarely in the stomachs, this study found no highly significant differences in the growth rates among the positions or among the digestion ranks (Tables $3 \& 4$ ). Therefore, we assumed that the predators continually preyed on larval anchovy from the same population in terms of growth rates by the time of capture, and that our results were not affected by predation due to exceptionally high larval density in the net.

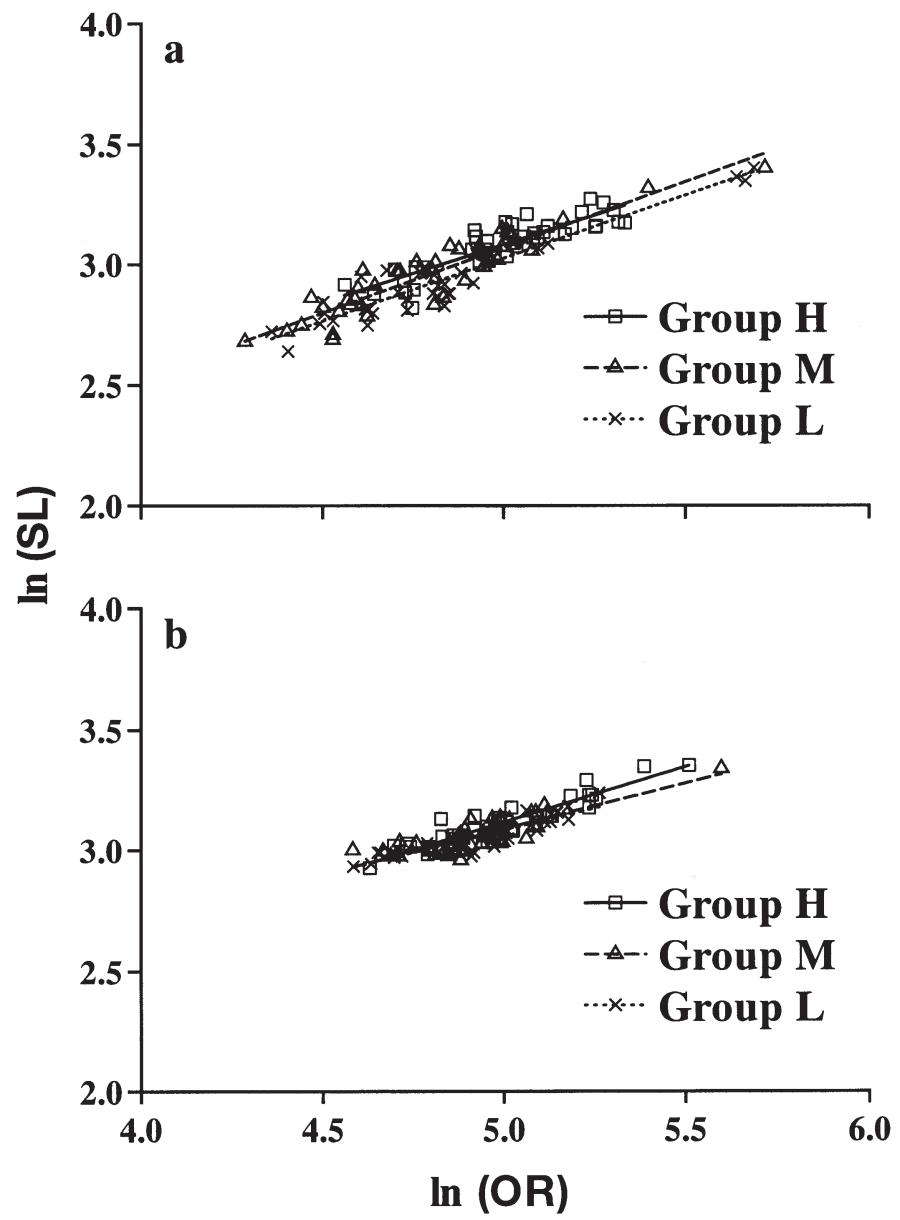

Fig. 3. Effects of growth rates on otolith radius-standard length (OR-SL) relationship of the surviving larvae, (a) $\mathrm{S}_{1}$ and (b) $\mathrm{S}_{2}$. The larvae were classified into 3 groups within each surviving larval sample according to the level of mean growth rates. Group H: high-order, 40 individuals; Group M: middle-order, 40 individuals; Group L: low-order, 40 individuals. Regressions of ln SL on ln OR were compared among the groups. (a) Group H: ln SL = $0.482 \ln \mathrm{OR}+0.676\left(\mathrm{r}^{2}=0.769, \mathrm{n}=40\right)$; Group M: ln $\mathrm{SL}=0.545 \ln \mathrm{OR}+0.349\left(\mathrm{r}^{2}=0.856, \mathrm{n}=40\right)$; Group $\mathrm{L}: \ln \mathrm{SL}=0.523 \ln \mathrm{OR}+0.414\left(\mathrm{r}^{2}=0.887, \mathrm{n}=40\right)$. (b) Group H: $\ln \mathrm{SL}=0.460 \ln \mathrm{OR}+0.816\left(\mathrm{r}^{2}=0.860, \mathrm{n}=40\right) ;$ Group M: $\ln \mathrm{SL}=0.379 \ln \mathrm{OR}+1.194\left(\mathrm{r}^{2}=0.714, \mathrm{n}=40\right) ;$ Group L: $\ln \mathrm{SL}=$ $0.367 \ln$ OR $+1.249\left(\mathrm{r}^{2}=0.796, \mathrm{n}=40\right)$

\section{Validation of SL restoration}

SL restoration allowed us to examine the growth rates of the prey larvae digested to varying degrees, partly in order to rule out predation in the net; however, the restoration should be validated in a way which avoids the results of growth comparison between the prey larvae and surviving larvae via its monistic estimation process. As previously reported for larval Japanese anchovy (Chiu \& Chen 2001, Takahashi et al. 2001), plots of SL against OR for the larvae in this study were also expressed as an allometric rela- 

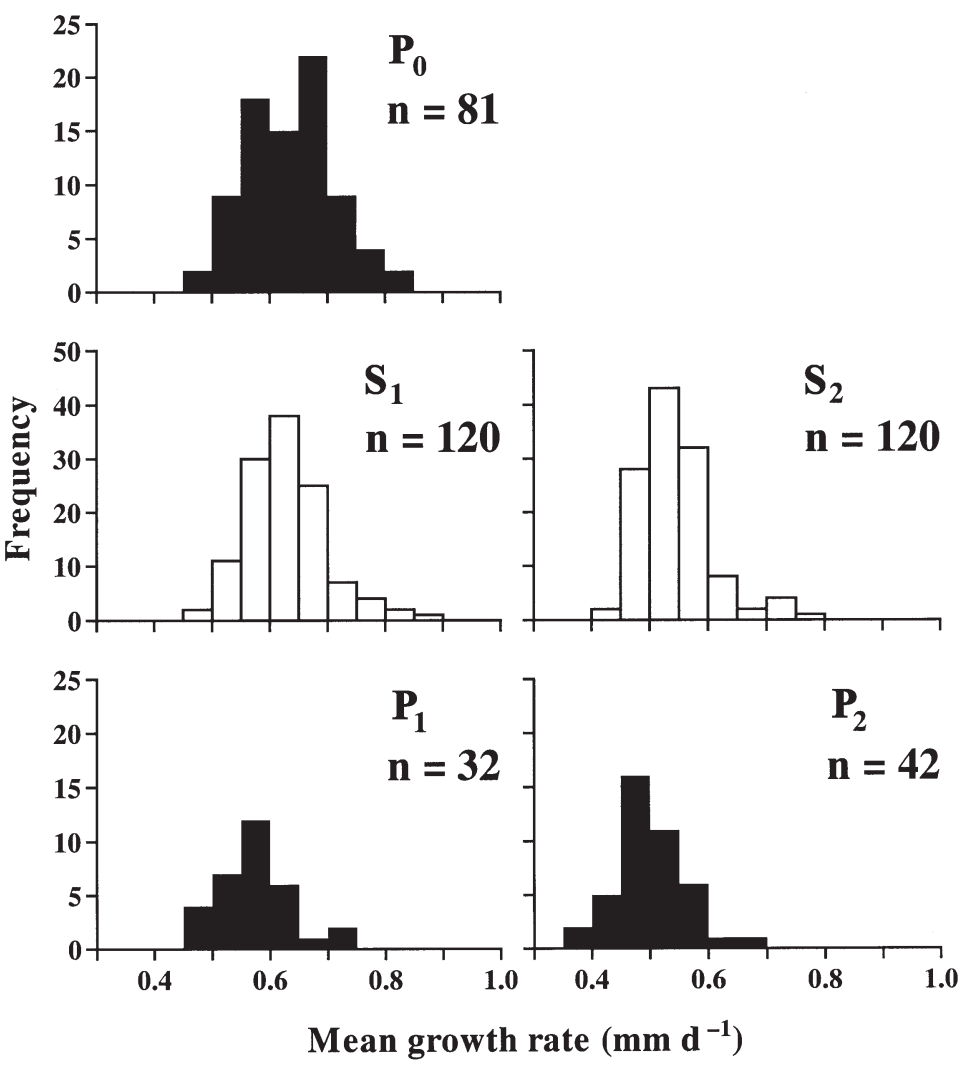

Fig. 4. Comparison of the mean growth rate frequencies between the prey larvae $\left(\mathrm{P}_{0}, \mathrm{P}_{1}\right.$ and $\left.\mathrm{P}_{2}\right)$ and surviving larvae $\left(\mathrm{S}_{1}\right.$ and $\left.\mathrm{S}_{2}\right)$

tionship. Somatic growth rates, however, could affect the OR-SL relationship (Templeman \& Squires 1956, Reznick et al. 1989, Secor \& Dean 1989, García et al. 1998). If so, the monistic restoration process could bias the SL estimates of the prey larvae.

Tests of the effects of growth rates on OR-SL relationships showed that lower growth larvae could have slightly larger otoliths at the same larval sizes (Fig. 3). This phenomenon is consistent with what has already been reported for guppy Poecilia reticulata (Reznick et al. 1989), larval and juvenile striped bass Morone saxatilis (Secor \& Dean 1989, 1992), larval and pelagic juvenile bluefish Pomatomus saltatrix (Hare \& Cowen 1995), European anchovy Engraulis encrasicolus larvae (García et al. 1998), and some other species (e.g. Hovenkamp 1990, Wright et al. 1990, Francis et al. 1993). It happens partly because slower growing larvae accumulate more increments in spite of their narrowness even while scarcely growing (Secor \& Dean 1989, Hare \& Cowen 1995, García et al. 1998). Uncoupling between otolith and somatic growth existed slightly in the present study. Nonetheless, such directional characteristics of this uncoupling do not affect the results of growth comparison, as follows: when the $\mathrm{SL}$ of a larva with lower growth rates is restored from an OR by the OR-SL relationship representative of the whole corresponding surviving larvae, the estimated SL value could be larger than the real value expected from the OR-SL relationship for the group with lower growth rates, and vice versa. Accordingly, use of SL data restored via such a monistic process tends to underestimate higher growth and overestimate lower growth. In other words, the variations in growth rates of the prey larvae would be reduced and consequently, the restoration process would not exaggerate the differences between the prey larvae and surviving larvae. Moreover, validation for the larvae with measured SLs available confirmed that there were no significant differences between restored estimates and actual measurements. Thus, SL restoration has been validated in the present samples.

\section{Comparison of growth rates between prey larvae and surviving larvae}

The mean growth rates of the prey larvae were significantly lower than those of the temporarily surviving larvae from the corresponding population of origin (Fig. 4). This obviously demonstrated that the individuals with higher growth rates were less vulnerable to predation than those with lower growth rates for larval Japanese anchovy in Sagami Bay. Consistent results from 2 cohorts with significantly different growth rates suggested that selective predation on lower growth larvae would depend, at least in part, on the relative values of individual growth rates within a cohort. Elucidation of the role of absolute values, which also might influence the intensity of selection and cohort survival, will need further research with quantitative sampling.

Meekan \& Fortier (1996) presented the results supporting the 'growth-mortality' hypothesis for larval Atlantic cod Gadus morhua by comparing growth histories of survivors with those of the population during earlier times in the field study. In a similar method, a higher survival probability for faster growing individuals was demonstrated for larval plaice Pleuronectes platessa (Hovenkamp 1992). Survivorship of larger members of a cohort of yellow perch Perca flavescens during its first growing season was tested by comparing the back-calculated size distribution of survivors 


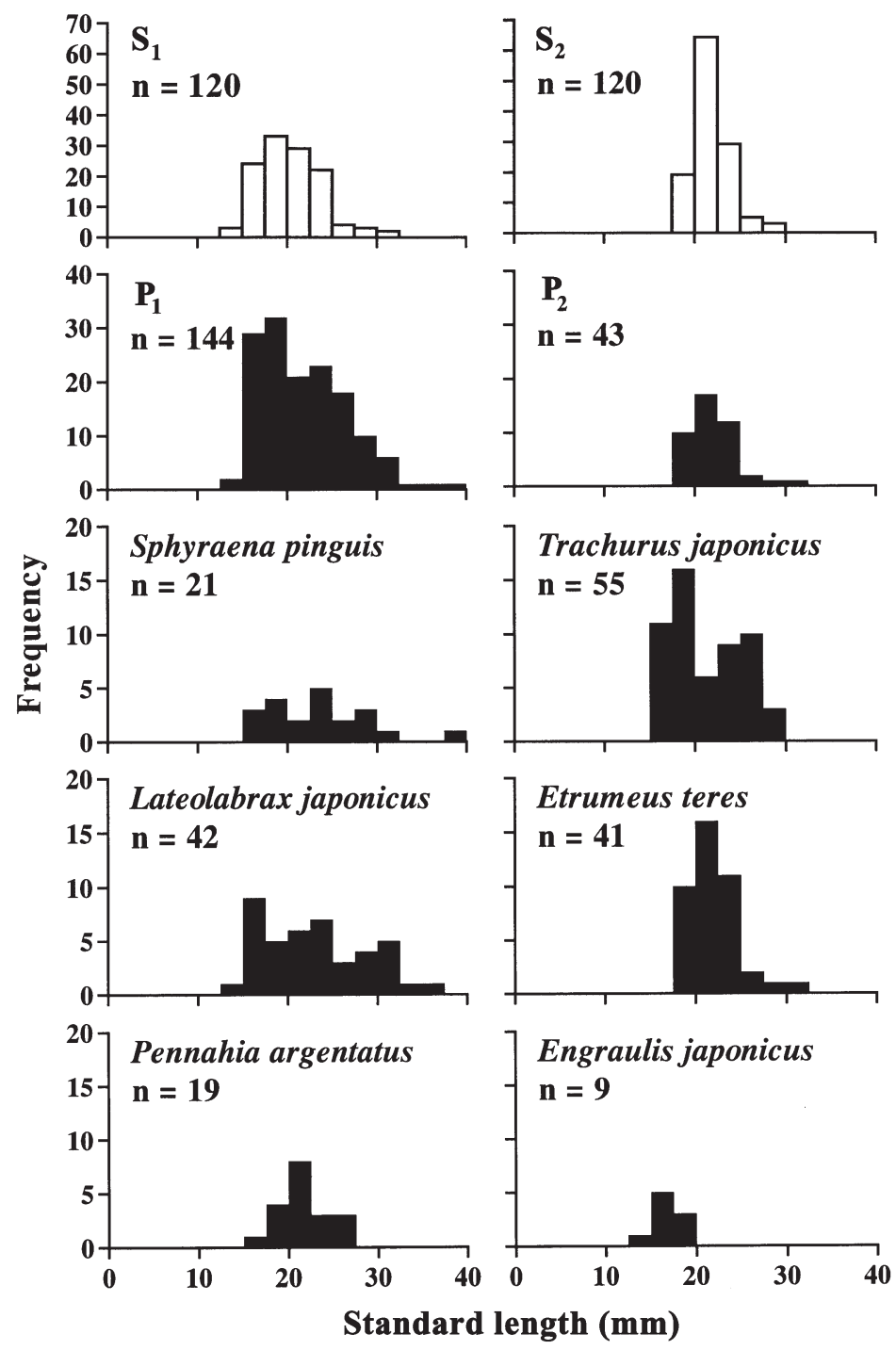

Fig. 5. Standard length (SL) frequencies of the larvae from the stomach contents of each predatory species and surviving larvae $\left(\mathrm{S}_{1}\right.$ and $\left.\mathrm{S}_{2}\right)$. Both measured SLs of the larvae with otoliths unavailable and restored SLs from otolith radius $(\mathrm{OR})$ data were also included. $\mathrm{P}_{0}$ is not separately shown but included in each predatory species. Three juvenile anchovy of $48.9,67.4$ and $69.5 \mathrm{~mm}$ SL from Sphyraena pinguis are not shown as prey individuals; a few juvenile anchovy $<40 \mathrm{~mm}$ SL are included. Etrumeus teres to be compared with only $\mathrm{S}_{2 i} S$. pinguis compared with both $\mathrm{S}_{1}$ and $\mathrm{S}_{2 i}$ the other species compared with only $\mathrm{S}_{1}$

with the size distribution observed earlier (Post \& Prankevicius 1987). Similarly, the other field tests of the 'growth-mortality' hypothesis and functional mechanisms have also been conducted based entirely on characteristics of survivors versus assumed population of origin including non-survivors (e.g. Healey 1982, West \& Larkin 1987, Butler \& Nishimoto 1997, Hare \& Cowen 1997, Sirois \& Dodson 2000, Good et al. 2001, Searcy \& Sponaugle 2001). They all provided the time-integrated picture of mortality over a longer period through larval (and juvenile) stage(s). Our study, on the other hand, presents the instantaneous image (snapshot) of predation mortality at just before the time of capture, independent of stage duration, and was able to directly examine the part of the population dead by predation for the first time, taking advantage of otoliths temporarily preserved in the stomachs. The results are a piece of evidence at a given moment in the field to support the predation part of the 'growth-mortality' hypothesis.

\section{Non-size-related predation mortality}

Size-related processes have been central to the role of growth in recruitment dynamics (e.g. Anderson 1988, Sogard 1997 for reviews). Negative size-selective predation mortality might be pervasive in accordance with the 'bigger is better' hypothesis, while survivorship of smaller individuals has been recognized. Fuiman (1989) and Litvak \& Leggett (1992) reported higher predation mortality experienced by older or larger larvae in their enclosure studies. In a series of laboratory and mesocosm experiments, positive sizeselective predation on young-of-the-year inland silverside Menidia beryllina by juvenile bluefish occurred (Gleason \& Bengtson 1996a), which was supported by a field study (Gleason \& Bengtson 1996b). Bailey \& Houde (1989) proposed a conceptual model in which vulnerability of eggs and larvae follows a dome-shaped function, depending on predator type, by using the prey/predator-size ratio, which seems a better perspective than either prey or predator size alone. This relationship was confirmed for various types of predators by Cowan et al. (1996) and Paradis et al. (1996). Such a dome-shaped curve was based on the component factors, such as encounter, attack and capture rates, as they play significant roles in the prey-predator relationship, while predatory gape limitation would simply contribute to decreases in vulnerability to predation with increasing prey size.

In a field study on the growth-mortality relationship, Hovenkamp (1992) suggested that size-selective mortality was not necessarily required in explaining the observed survival ratios of larval plaice in his demon- 


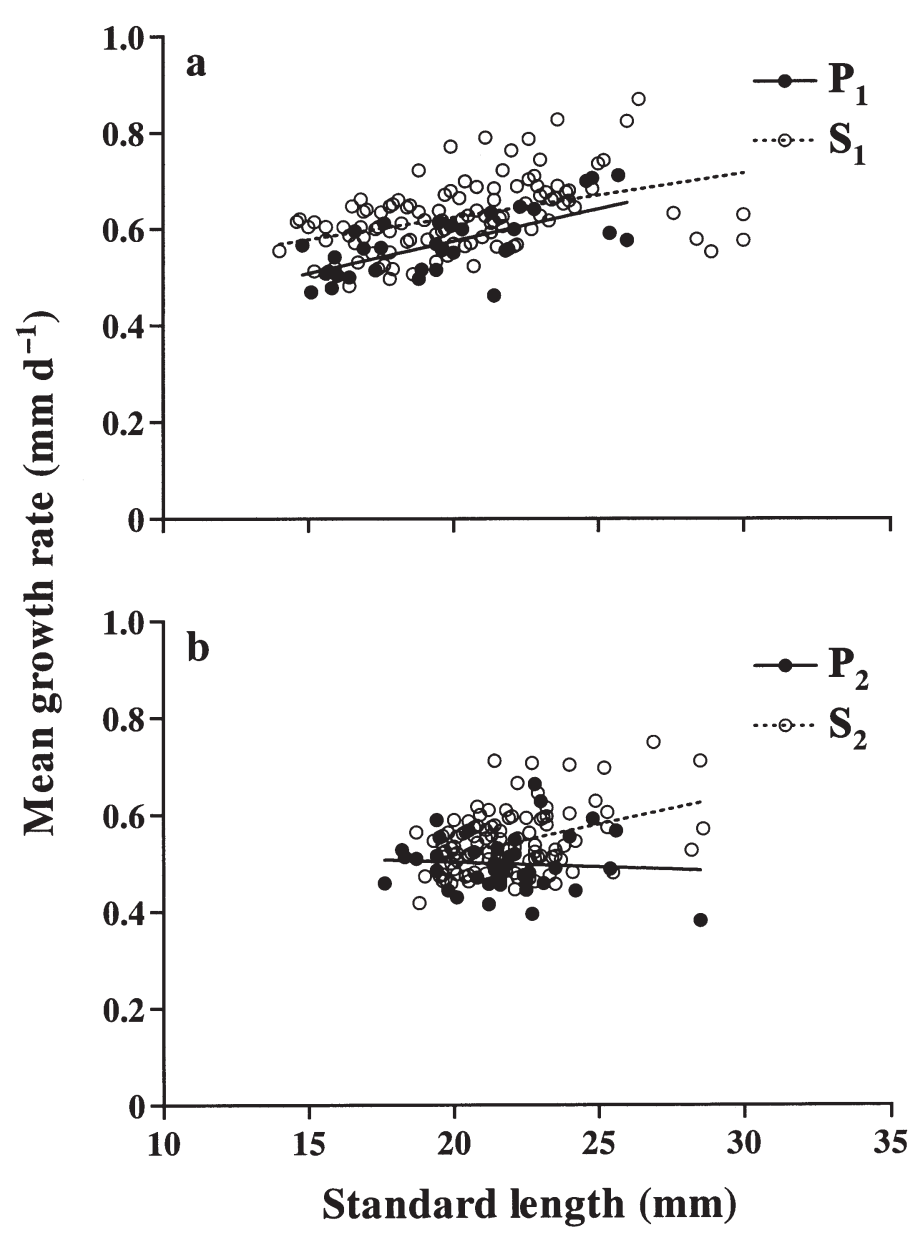

Fig. 6. Regressions of mean growth rate on standard length (SL) for the prey larvae $\left(\mathrm{P}_{1}\right.$ and $\left.\mathrm{P}_{2}\right)$ and surviving larvae $\left(\mathrm{S}_{1}\right.$ and $\left.\mathrm{S}_{2}\right)$. (a) $\mathrm{P}_{1}$ : GR (mean growth rate) $=0.013 \mathrm{SL}+0.307\left(\mathrm{r}^{2}=\right.$ $0.443, \mathrm{n}=32) ; \mathrm{S}_{1}: \mathrm{GR}=0.009 \mathrm{SL}+0.440\left(\mathrm{r}^{2}=0.184, \mathrm{n}=120\right)$. (b) $\mathrm{P}_{2}: \mathrm{GR}=-0.002 \mathrm{SL}+0.541\left(\mathrm{r}^{2}=0.005, \mathrm{n}=42\right)$; $\mathrm{S}_{2}: \mathrm{GR}=0.013 \mathrm{SL}+0.263\left(\mathrm{r}^{2}=0.154, \mathrm{n}=120\right)$

stration for growth-dependent mortality (the 'stage duration' concept). The direction of size-selective mortality of Atlantic salmon Salmo salar fry reversed over 2 consecutive summers, in association with hydroclimatic events (Good et al. 2001). Leggett \& DeBlois (1994) concluded that neither the 'bigger is better' nor the 'stage duration' hypothesis was unequivocally supported in their evaluation of these hypotheses.

In our study, both negative and positive sizeselective predation mortalities were observed, depending on the predatory species. However, the combined effects of all predators were neutral, showing no sizeselective predation in the whole mixed-species predator field (Fig. 5), although the predator compositions in this study may not exactly represent all potential predators in the study area. Purcell (1985) and Sogard (1997) noticed equivocality for extrapolation of singlespecies prey-size preference to the natural multi-species

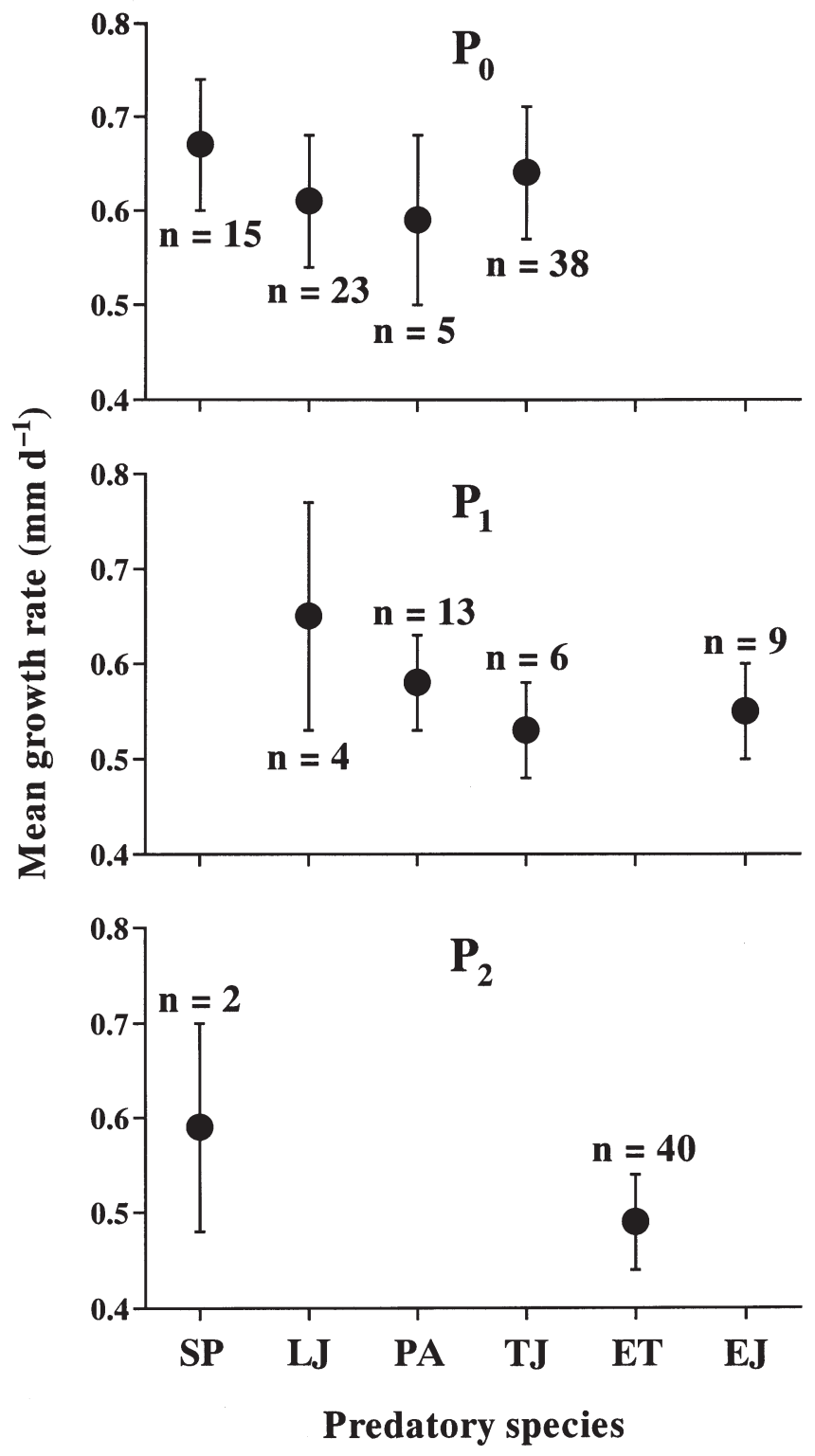

Fig. 7. Comparison of the mean growth rates of the prey larvae $\left(\mathrm{P}_{0}, \mathrm{P}_{1}\right.$ and $\left.\mathrm{P}_{2}\right)$ among their predatory species. $\mathrm{SP}$ : Sphyraena pinguis; LJ: Lateolabrax japonicus; PA: Pennahia argentatus; TJ: Trachurus japonicus; ET: Etrumeus teres; EJ: Engraulis japonicus. Mean $\pm \mathrm{SD}$ indicated in the diagram

predator field. Substantial size-selective mortality should depend on the natural predator field experienced by a population or cohort. In short, size-selective mortality is neither universal nor unidirectional. The existence of some non-size-related effects of growth on predation mortality, given that individuals with higher growth rates finally gain survivorship, is implied.

Fig. 6 clarifies the above. The significant differences in growth rates between the prey larvae and the corresponding surviving larvae were still visible in comparisons at the same size. Slower growing individuals are 

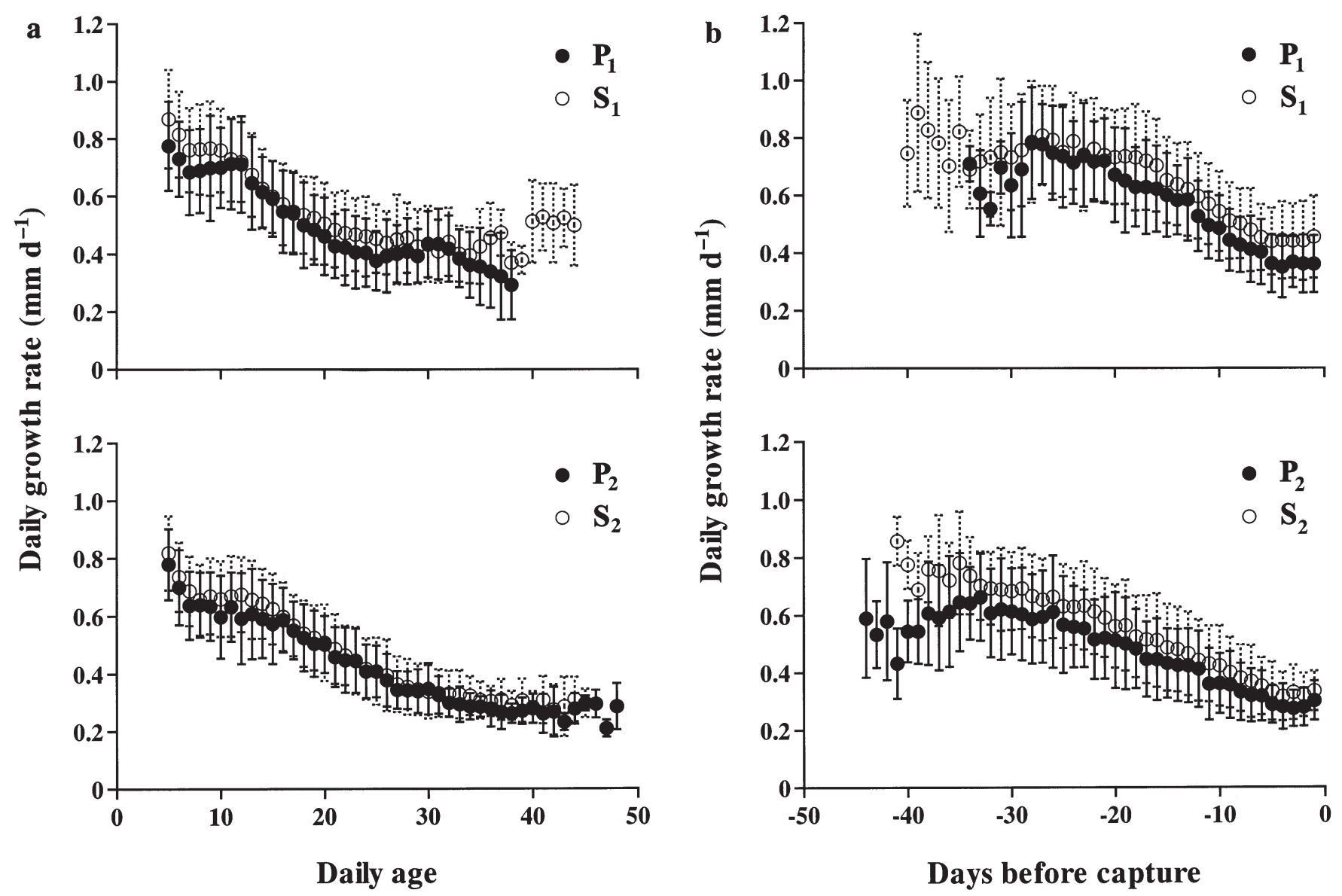

Fig. 8. Back-calculated daily growth rates of the prey larvae $\left(\mathrm{P}_{1}\right.$ and $\left.\mathrm{P}_{2}\right)$ and surviving larvae $\left(\mathrm{S}_{1}\right.$ and $\left.\mathrm{S}_{2}\right)$. Data were pooled by (a) daily age and (b) days before capture. Mean \pm SD shown at each daily age with at least 3 back-calculated growth rate data available

more vulnerable to predation mortality than faster growing conspecifics, even if they are the same size (i.e. non-size-related), at a given moment in the sea. This means that the level of growth rate itself had direct impact on the vulnerability to predation of the larval Japanese anchovy, independently of both size (negative size-selective mortality) and time (stage duration). We propose the 'growth-selective predation' hypothesis (mechanism), which is theoretically independent of and synergistic with the existing hypotheses based on size and time under a general concept of the 'growth-mortality' hypothesis and extend it.

\section{Differences among predatory species}

Although the sample sizes in the present study might be considered small, and the effects of size-selective predation cannot be completely discounted for each predatory species considering positive relationships between size and growth rates (Fig. 6), differences in growth rates of the prey larvae among predatory spe- cies suggest that such impacts could be predator-specific (Fig. 7). Larger and strongly piscivorous predators, such as barracuda, may weakly or not select larvae by growth rates, while smaller predators such as Pacific round herring and juvenile anchovy might prey more selectively on larvae with lower growth rates. In the conceptual model, functions of vulnerability to predation on the prey/predator-size ratio depend on predator types (e.g. filter-feeding or raptorial feeding in Bailey \& Houde 1989). In a simulation by Chick \& Van Den Avyle (2000), the influences of growth and condition on cohort mortality rate for larval striped bass varied between 2 potential predators, Alosa aestivalis and Pomoxis nigromaculatus, for which simulation models were constructed. As for size-selective mortality, Post \& Prankevicius (1987) mentioned the difference in predator guilds as one of the reasons why the strength of size-selective mortality varied between 2 lakes. In that study, strong removal of smaller yellow perch was found in the lake dominated by gapelimited predators, whereas the other lake was characterized by larger predators, which were expected to 
potentially prey on all size classes. Predator-specific impacts, if ever, would be closely related to the feeding habit and ecology of each predatory species.

\section{Ontogenetic and temporal changes in growth rates up to the time of capture or predation}

Back-calculated daily growth rates pooled by daily age closely match ontogenetic changes in growth rates, including stage-specific growth. Comparisons of the $5 \mathrm{~d}$ mean growth rates pooled by daily age indicated that differences in growth between the prey larvae and surviving larvae had already arisen at least during the prelarval stage, immediately after hatching (Fig. 8a). When data were pooled by daily age, however, temporal changes with real time and trends in older ages were not be considered highly reliable, since there were some time lags among hatching dates in each sample (Fig. 1) and the pooled number decreases with daily age. On the other hand, data pooled by days before capture are well suited to temporal changes with real time before capture, although stage-specific changes and growth history directly after hatching may be masked. The prey larvae were shown to have consistently lower growth rates than the surviving larvae in data pooled by days before capture (Fig. 8b) as well as in data pooled by daily age, suggesting that the instantaneous predation mortality depends on a longterm decline in growth rates from directly after hatching to each encounter with predators. The cumulative decline in growth rates was determinative, rather than a temporary decline at specific stages or just before predation.

\section{Potential for anti-predator behaviors and 'growth-selective predation'}

Differences in potential for anti-predator behaviors, such as escape activity and responsiveness in encountering predators, might be the best explanation for the causal background of 'growth-selective predation'. As seen in the studies on selective mortality, most prey-predator interactions have been explained in terms of size-related factors. The case is true for vulnerability to predation composed of a variety of antipredator behaviors. Webb (1981) recorded responses of larval northern anchovy Engraulis mordax to attacks by a biting planktivore, clown fish, on video tape and reported that the proportion of larvae responding to and escaping predator attacks, the escape distances traveled and the mean escape speeds increased linearly with larval size. Similarly, many studies have reported improvement of a variety of anti-predator performance and decreased susceptibility to predation in relation to size (Webb \& Corolla 1981, Bailey 1984, Bailey \& Batty 1984, Brownell 1985, Blaxter 1986, Folkvord \& Hunter 1986, Purcell et al. 1987, Miller et al. 1988, Williams \& Brown 1992, Fuiman 1993, Williams et al. 1996), age (Butler \& Pickett 1988, Sugisaki et al. 2001) and developmental stage (Bailey \& Batty 1984, Purcell et al. 1987, Fisher et al. 2000, Wennhage 2000).

An exception to the focus on ontogenetic changes was presented by Chick \& Van Den Avyle (2000). In their laboratory experiments and subsequent simulations, the effects of feeding ration on swimming speed and responsiveness to simulated predator attacks were examined for larval striped bass. Larvae in the lowfeeding treatment had slower swimming speeds and less responsiveness to predator attacks. Although their model simulated cohort mortality and not individual mortality, the emphasis of non-size-related nutritional condition on vulnerability to predation was addressed. A prevailing scenario for the larval survival process is that environmental factors, such as food availability and temperature, determine both larval condition and growth, which can then ultimately determine the predation mortality, as suggested in the 'growth-mortality' hypothesis. Indirect evidence has been obtained for the relationships among condition, growth and susceptibility to predation. Frank \& Leggett (1982) showed the correlation between environmentally regulated condition and swimming ability for larval capelin Mallotus villosus. Similarly, starvation has been shown to depress responsiveness to predator attacks and escape ability, mediated by deterioration in condition (Yin \& Blaxter 1987, Booman et al. 1991, Booth \& Hixon 1999). These authors highlighted the potential effects of food ration and condition on survival, as did Chick \& Van Den Avyle (2000). An update of the field test of the 'growth-mortality' hypothesis was introduced by Searcy \& Sponaugle (2001). They found selective mortality acting on a growth-based characteristic but equivocality for size-selective mortality for 2 coral reef fishes (Labridae), based on comparisons of otolith-derived traits between survivors and initial groups. Detected selective mortality in their study was the time-integrated mortality through metamorphosis and early juvenile period, yet it can be in accordance with the instantaneous predation mortality in our demonstration, in that selection was based not on size but on nonsize-related growth variations. Searcy \& Sponaugle (2001) attributed such selective mortality to physiological condition. What is given to vulnerability to predation by variations in nutritional (physiological) condition, as well as size, age and stage-related factors, is supposed to run by non-size-related growth rate variations. Synthetically, the deductive inference is that the 
non-size-related 'growth-selective predation' would also be a ramification of differences in potential for anti-predator behaviors.

Within-population or cohort survival process depending on such potential of individual larvae could be associated with larval shoaling. One of the evolutionary functions of the shoals is well known as a defense against predation (Magurran 1990, Pitcher \& Parrish 1993). The jacks Caranx ignobilis broke up the shoals of anchovy Stolephorus purpureus and then captured isolated individuals in an enclosure (Major 1978). Individuals separated from the shoals are considered to be more easily captured by the predators through failure to share defensive advantages of shoals (Neill \& Cullen 1974, Parrish 1989, Pitcher \& Parrish 1993). Mesa et al. (1994) reviewed the experimental studies on prey-predator interactions where prey were put into substandard condition artificially, with toxicants, thermal shocks, physical stresses, disease or starvation. They mentioned, although speculatively, disruption of the shoaling behavior of prey as one possible mechanism underlying increased vulnerability of substandard prey to predation. Postlarval anchovy generally form shoals with high density (Mitani 1988), as is often the case with the adult anchovy and many other pelagic species. When a larval shoal is attacked by predators, lower growth larvae, if the same in size, may tend to become isolated from their companions, probably because of their lower responsiveness to predators and swimming activity, and end up becoming more vulnerable to predation. If differences in potential for anti-predator behaviors and related shoaling behaviors are responsible for the 'growth-selective predation', the characteristics of each predator should be significant. This would also explain the differences among predatory species discussed above.

\section{Significance of 'growth-selective predation' and further study}

Prey-size selection is often explained by optimal foraging theory (see Hart 1993, Gerking 1994 for reviews). In this theory, the forager attempts to maximize the rate of food consumption per unit time (Wootton 1998). This will be determined under a trade-off between net gain as energy and cost as handling time. Hence, a little decline in prey size could mean much energy loss, since the energy content provided by the consumed prey would be proportional to its weight, which increases exponentially with length. Selectivity on lower growth prey, however, would lead to little if any energy loss in spite of ease of capture, as far as among individual prey of the same length. The 'growth-selective predation' would also be theoretically rational on the side of predators in terms of benefit versus cost, since it would almost unidirectionally lead to improved prey capture facilities for predators.

Further studies on the 'growth-selective predation' should be conducted from 3 viewpoints. First, we may reveal predator-specific impacts by collecting a larger number of various predators and examining their feeding ecology in detail. Secondly, differences among seasons should be examined since the growth rates of the larvae in this study were relatively low, probably owing to lower sea temperature in autumn. Selection for fast growth might be stronger in a slower growing group (Post \& Prankevicius 1987, Meekan \& Fortier 1996). Also, the predator field would temporally vary. Finally, ontogenetic changes would be of concern. Sissenwine (1984) emphasized the significance of predation on juvenile stages, and Watanabe et al. (1995) pointed out the importance of cumulative mortality after the first feeding stage rather than episodic mortality during larval stage as determinants of recruitment success. Growth and survival would be specific to each life history stage (Anderson 1988). It is necessary to determine the threshold and terminal limit of the impacts through larval and juvenile stages in order to identify the 'window' of vulnerability to predation.

Acknowledgements. We express our sincere thanks to C. Fukawa and Y. Fukawa for their support in field sampling with the 'shirasu' fishing boat Yoshiei-maru. Also, we are very grateful to 3 anonymous referees for their comments.

\section{LITERATURE CITED}

Anderson JT (1988) A review of size dependent survival during pre-recruit stages of fishes in relation to recruitment. J Northwest Atl Fish Sci 8:55-66

Aoki I, Miyashita K (2000) Dispersal of larvae and juveniles of Japanese anchovy Engraulis japonicus in the Kuroshio Extension and Kuroshio-Oyashio transition regions, western North Pacific Ocean. Fish Res 49:155-164

Bailey KM (1984) Comparison of laboratory rates of predation on five species of marine fish larvae by three planktonic invertebrates: effects of larval size on vulnerability. Mar Biol 79:303-309

Bailey KM, Batty RS (1984) Laboratory study of predation by Aurelia aurita on larvae of cod, flounder, plaice and herring: development and vulnerability to capture. Mar Biol 83:287-291

Bailey KM, Houde ED (1989) Predation on eggs and larvae of marine fishes and the recruitment problem. Adv Mar Biol 25:1-83

Bailey KM, Brodeur RD, Merati N, Yoklavich MM (1993) Predation on walleye pollock (Theragra chalcogramma) eggs and yolk-sac larvae by pelagic crustacean invertebrates in the western Gulf of Alaska. Fish Oceanogr 2:30-39

Blaxter JHS (1986) Development of sense organs and behaviour of teleost larvae with special reference to feeding and predator avoidance. Trans Am Fish Soc 115:98-114

Booman C, Folkvord A, Hunter JR (1991) Responsiveness of 
starved northern anchovy Engraulis mordax larvae to predation attacks by adult anchovy. Fish Bull 89:707-711

Booth DJ, Hixon MA (1999) Food ration and condition affect early survival of the coral reef damselfish, Stegastes partitus. Oecologia 121:364-368

Brownell CL (1985) Laboratory analysis of cannibalism by larvae of the Cape anchovy Engraulis capensis. Trans Am Fish Soc 114:512-518

Butler JL, Nishimoto RN (1997) Growth and cohort dynamics of larval Pacific hake (Merluccius productus). Calif Coop Ocean Fish Investig Rep 38:63-68

Butler JL, Pickett D (1988) Age-specific vulnerability of Pacific sardine, Sardinops sagax, larvae to predation by northern anchovy, Engraulis mordax. Fish Bull 86:163-167

Campana SE (1990) How reliable are growth back-calculations based on otoliths? Can J Fish Aquat Sci 47:2219-2227

Campana SE (1996) Year-class strength and growth rate in young Atlantic cod Gadus morhua. Mar Ecol Prog Ser 135:21-26

Campana SE, Jones CM (1992) Analysis of otolith microstructure data. Can Spec Publ Fish Aquat Sci 117:73-100

Chambers RC, Leggett WC (1987) Size and age at metamorphosis in marine fishes: an analysis of laboratory-reared winter flounder (Pseudopleuronectes americanus) with a review of variation in other species. Can J Fish Aquat Sci 44:1936-1947

Chick JH, Van Den Avyle MJ (2000) Effects of feeding ration on larval swimming speed and responsiveness to predator attacks: implications for cohort survival. Can J Fish Aquat Sci 57:106-115

Chiu TS, Chen CS (2001) Growth and temporal variation of two Japanese anchovy cohorts during their recruitment to the East China Sea. Fish Res 53:1-15

Cowan JH Jr, Houde ED, Rose KA (1996) Size-dependent vulnerability of marine fish larvae to predation: an individual-based numerical experiment. ICES J Mar Sci 53: 23-37

Cushing DH (1975) Marine ecology and fisheries. Cambridge University Press, Cambridge

Cushing DH (1990) Plankton production and year-class strength in fish populations: an update of the match/ mismatch hypothesis. Adv Mar Biol 26:249-293

Cushing DH (1995) A comment on Leggett \& DeBlois. Mar Ecol Prog Ser 128:305-306

Fisher R, Bellwood DR, Job SD (2000) Development of swimming abilities in reef fish larvae. Mar Ecol Prog Ser 202: 163-173

Folkvord A, Hunter JR (1986) Size-specific vulnerability of northern anchovy, Engraulis mordax, larvae to predation by fishes. Fish Bull 84:859-869

Francis MP, Williams MW, Pryce AC, Pollard S, Scott SG (1993) Uncoupling of otolith and somatic growth in Pagrus auratus (Sparidae). Fish Bull 91:159-164

Frank KT, Leggett WC (1982) Environmental regulation of growth rate, efficiency, and swimming performance in larval capelin (Mallotus villosus), and its application to the match/mismatch hypothesis. Can J Fish Aquat Sci 39:691-699

Fuiman LA (1989) Vulnerability of Atlantic herring larvae to predation by yearling herring. Mar Ecol Prog Ser 51:291-299

Fuiman LA (1993) Development of predator evasion in Atlantic herring, Clupea harengus L. Anim Behav 45:1101-1116

Fukuhara O (1983) Development and growth of laboratory reared Engraulis japonica (Houttuyn) larvae. J Fish Biol 23:641-652

Fukuhara O, Takao K (1988) Growth and larval behaviour of Engraulis japonica in captivity. J Appl Ichthyol 4:158-167
García A, Cortés D, Ramírez T (1998) Daily larval growth and RNA and DNA content of the NW Mediterranean anchovy Engraulis encrasicolus and their relations to the environment. Mar Ecol Prog Ser 166:237-245

Gerking SD (1994) Feeding ecology of fish. Academic Press, London

Gleason TR, Bengtson DA (1996a) Growth, survival and sizeselective predation mortality of larval and juvenile inland silversides, Menidia beryllina (Pisces; Atherinidae). J Exp Mar Biol Ecol 199:165-177

Gleason TR, Bengtson DA (1996b) Size-selective mortality of inland silversides: evidence from otolith microstructure. Trans Am Fish Soc 125:860-873

Good SP, Dodson JJ, Meekan MG, Ryan DAJ (2001) Annual variation in size-selective mortality of Atlantic salmon (Salmo salar) fry. Can J Fish Aquat Sci 58:1187-1195

Hare JA, Cowen RK (1995) Effect of age, growth rate, and ontogeny on the otolith size - fish size relationship in bluefish, Pomatomus saltatrix, and the implications for backcalculation of size in fish early life history stages. Can J Fish Aquat Sci 52:1909-1922

Hare JA, Cowen RK (1997) Size, growth, development, and survival of the planktonic larvae of Pomatomus saltatrix (Pisces: Pomatomidae). Ecology 78:2415-2431

Hart PJB (1993) Foraging in teleost fishes. In: Pitcher TJ (ed) Behaviour of teleost fishes. Chapman \& Hall, London, p 253-284

Healey MC (1982) Timing and relative intensity of size-selective mortality of juvenile chum salmon (Oncorhynchus keta) during early sea life. Can J Fish Aquat Sci 39:952-957

Heath MR (1992) Field investigations of the early life stages of marine fish larvae. Adv Mar Biol 28:1-174

Hjort J (1914) Fluctuations in the great fisheries of northern Europe viewed in the light of biological research. Rapp P-V Reun Cons Int Explor Mer 20:1-228

Houde ED (1987) Fish early life dynamics and recruitment variability. Am Fish Soc Symp 2:17-29

Houde ED (1989) Subtleties and episodes in the early life of fishes. J Fish Biol 35(Suppl A):29-38

Hovenkamp F (1990) Growth differences in larval plaice Pleuronectes platessa in the Southern Bight of the North Sea as indicated by otolith increments and RNA/DNA ratios. Mar Ecol Prog Ser 58:205-215

Hovenkamp F (1992) Growth-dependent mortality of larval plaice Pleuronectes platessa in the North Sea. Mar Ecol Prog Ser 82:95-101

Kraufvelin P (1999) Baltic hard bottom mesocosms unplugged: replicability, repeatability and ecological realism examined by non-parametric multivariate techniques. J Exp Mar Biol Ecol 240:229-258

Lasker R (1975) Field criteria for survival of anchovy larvae: the relation between inshore chlorophyll maximum layers and successful first feeding. Fish Bull 73:453-462

Lasker R (1978) The relation between oceanographic conditions and larval anchovy food in the California Current: identification of factors contributing to recruitment failure. Rapp P-V Reun Cons Int Explor Mer 173:212-230

Leggett WC, DeBlois E (1994) Recruitment in marine fishes: Is it regulated by starvation and predation in the egg and larval stages? Neth J Sea Res 32:119-134

Lindsay DJ, Minagawa M, Mitani I, Kawaguchi K (1998) Trophic shift in the Japanese anchovy Engraulis japonicus in its early life history stages as detected by stable isotope ratios in Sagami Bay, Central Japan. Fish Sci 64:403-410

Litvak MK, Leggett WC (1992) Age and size-selective predation on larval fishes: the bigger-is-better hypothesis revisited. Mar Ecol Prog Ser 81:13-24 
Magurran AE (1990) The adaptive significance of schooling as an anti-predator defence in fish. Ann Zool Fenn 27: $51-66$

Major PF (1978) Predator-prey interactions in two schooling fishes, Caranx ignobilis and Stolephorus purpureus. Anim Behav 26:760-777

Meekan MG, Fortier L (1996) Selection for fast growth during the larval life of Atlantic cod Gadus morhua on the Scotian Shelf. Mar Ecol Prog Ser 137:25-37

Mesa MG, Poe TP, Gadomski DM, Petersen JH (1994) Are all prey created equal? A review and synthesis of differential predation on prey in substandard condition. J Fish Biol 45(Suppl A):81-96

Miller TJ, Crowder LB, Rice JA, Marschall EA (1988) Larval size and recruitment mechanisms in fishes: toward a conceptual framework. Can J Fish Aquat Sci 45:1657-1670

Mitani I (1988) Characteristics of daily age composition of larvae of Japanese anchovy Engraulis japonica in the fishing ground in Sagami Bay. Nippon Suisan Gakkaishi 54: 209-214

Neill SRStJ, Cullen JM (1974) Experiments on whether schooling by their prey affects the hunting behaviour of cephalopods and fish predators. J Zool 172:549-569

Paradis AR, Pepin P, Brown JA (1996) Vulnerability of fish eggs and larvae to predation: review of the influence of the relative size of prey and predator. Can J Fish Aquat Sci 53:1226-1235

Parrish JK (1989) Re-examining the selfish herd: are central fish safer? Anim Behav 38:1048-1053

Pepin P, Shears TH, de Lafontaine Y (1992) Significance of body size to the interaction between a larval fish (Mallotus villosus) and a vertebrate predator (Gasterosteus aculeatus). Mar Ecol Prog Ser 81:1-12

Pitcher TJ, Parrish JK (1993) Functions of shoaling behaviour in teleosts. In: Pitcher TJ (ed) Behaviour of teleost fishes. Chapman \& Hall, London, p 363-439

Post JR, Prankevicius AB (1987) Size-selective mortality in young-of-the-year yellow perch (Perca flavescens): evidence from otolith microstructure. Can J Fish Aquat Sci 44:1840-1847

Purcell JE (1985) Predation on fish eggs and larvae by pelagic cnidarians and ctenophores. Bull Mar Sci 37:739-755

Purcell JE, Siferd TD, Marliave JB (1987) Vulnerability of larval herring (Clupea harengus pallasi) to capture by the jellyfish Aequorea victoria. Mar Biol 94:157-162

Reznick D, Lindbeck E, Bryga H (1989) Slower growth results in larger otoliths: an experimental test with guppies (Poecilia reticulata). Can J Fish Aquat Sci 46:108-112

Rice JA, Miller TJ, Rose KA, Crowder LB, Marschall EA, Trebitz AS, DeAngelis DL (1993) Growth rate variation and larval survival: inferences from an individual-based size-dependent predation model. Can J Fish Aquat Sci 50: 133-142

Searcy SP, Sponaugle S (2001) Selective mortality during the larval-juvenile transition in two coral reef fishes. Ecology 82:2452-2470

Secor DH, Dean JM (1989) Somatic growth effects on the otolith-fish size relationship in young pond-reared striped bass, Morone saxatilis. Can J Fish Aquat Sci 46:113-121

Secor DH, Dean JM (1992) Comparison of otolith-based backcalculation methods to determine individual growth histories of larval striped bass, Morone saxatilis. Can J Fish Aquat Sci 49:1439-1454

Shepherd JG, Cushing DH (1980) A mechanism for densitydependent survival of larval fish as the basis of a stockrecruitment relationship. J Cons Int Explor Mer 39:160-167

Sirois P, Dodson JJ (2000) Critical periods and growth- dependent survival of larvae of an estuarine fish, the rainbow smelt Osmerus mordax. Mar Ecol Prog Ser 203: 233-245

Sissenwine MP (1984) Why do fish populations vary? In: May RM (ed) Exploitation of marine communities. SpringerVerlag, Berlin, p 59-94

Sogard SM (1997) Size-selective mortality in the juvenile stage of teleost fishes: a review. Bull Mar Sci 60:1129-1157

Sugisaki H, Bailey KM, Brodeur RD (2001) Development of the escape response in larval walleye pollock (Theragra chalcogramma). Mar Biol 139:19-24

Takahashi M, Watanabe Y, Kinoshita T, Watanabe C (2001) Growth of larval and early juvenile Japanese anchovy, Engraulis japonicus, in the Kuroshio-Oyashio transition region. Fish Oceanogr 10:235-247

Templeman W, Squires HJ (1956) Relationship of otolith lengths and weights in the haddock Melanogrammus aeglefinus (L.) to the rate of growth of the fish. J Fish Res Board Can 13:467-487

Tsuji S, Aoyama T (1984) Daily growth increments in otoliths of Japanese anchovy larvae Engraulis japonica. Bull Jpn Soc Sci Fish 50:1105-1108

Tsukamoto K, Kuwada H, Hirokawa J, Oya M, Sekiya S, Hujimoto H, Imaizumi K (1989) Size-dependent mortality of red sea bream, Pagrus major, juveniles released with fluorescent otolith-tags in News Bay, Japan. J Fish Biol 35(Suppl A):59-69

Wang YT, Tzeng WN (1999) Differences in growth rates among cohorts of Encrasicholina punctifer and Engraulis japonicus larvae in the coastal waters off Tanshui River Estuary, Taiwan, as indicated by otolith microstructure analysis. J Fish Biol 54:1002-1016

Ware DM (1975) Relation between egg size, growth, and natural mortality of larval fish. J Fish Res Board Can 32: $2503-2512$

Watanabe Y, Kuroki T (1997) Asymptotic growth trajectories of larval sardine (Sardinops melanostictus) in the coastal waters off western Japan. Mar Biol 127:369-378

Watanabe Y, Zenitani H, Kimura R (1995) Population decline of the Japanese sardine Sardinops melanostictus owing to recruitment failures. Can J Fish Aquat Sci 52:1609-1616

Webb PW (1981) Responses of northern anchovy, Engraulis mordax, larvae to predation by a biting planktivore, Amphiprion percula. Fish Bull 79:727-735

Webb PW, Corolla RT (1981) Burst swimming performance of northern anchovy, Engraulis mordax, larvae. Fish Bull 79:143-150

Wennhage H (2000) Vulnerability of settling plaice Pleuronectes platessa to predation: effects of developmental stage and alternative prey. Mar Ecol Prog Ser 203: 289-299

West CJ, Larkin PA (1987) Evidence for size-selective mortality of juvenile sockeye salmon (Oncorhynchus nerka) in Babine Lake, British Columbia. Can J Fish Aquat Sci 44: 712-721

Williams PJ, Brown JA (1992) Development changes in the escape response of larval winter flounder Pleuronectes americanus from hatch through metamorphosis. Mar Ecol Prog Ser 88:185-193

Williams PJ, Brown JA, Gotceitas V, Pepin P (1996) Developmental changes in escape response performance of five species of marine fish. Can J Fish Aquat Sci 53:1246-1253

Wilson DT, Meekan MG (2002) Growth-related advantages for survival to the point of replenishment in the coral reef fish Stegastes partitus (Pomacentridae). Mar Ecol Prog Ser 231:247-260 
Wootton RJ (1998) Ecology of teleost fishes. Kluwer Academic Publishers, Dordrecht

Wright PJ, Metcalfe NB, Thorpe JE (1990) Otolith and somatic growth rates in Atlantic salmon parr, Salmo salar L: evidence against coupling. J Fish Biol 36: 241-249

Yamashita Y, Nagahora S, Yamada H, Kitagawa D (1994)

Editorial responsibility: Otto Kinne (Editor),

Oldendorf/Luhe, Germany
Effects of release size on survival and growth of Japanese flounder Paralichthys olivaceus in coastal waters off Iwate Prefecture, northeastern Japan. Mar Ecol Prog Ser 105: 269-276

Yin MC, Blaxter JHS (1987) Escape speeds of marine fish larvae during early development and starvation. Mar Biol 96:459-468

Submitted: July 22, 2002; Accepted: January 23, 2003

Proofs received from author(s): March 31, 2003 